\title{
Syed Waris Ameer Ali CIE
}

On October 5th 1928 Waris Ameer Ali, an Indian civil servant of Islamic and British descent, was elected a member of the Executive Committee of the Society for the Preservation of the Fauna of the Empire-now the Fauna Preservation Society. From that date, until failing health prevented him (apart from two periods of compulsory retirement under the Rules) it is hardly possible to find a single meeting which he did not attend-first as a Council member and, since April 1963, as a Vice-President. Such a record would be hard to rival in any society. He died on April 2nd, aged eighty-eight.

Nor was Waris merely a committee man. His first recorded activity for the Society was an address in 1929 to the East Indian Association which starts, 'One body of God's creatures has been, doubtless unwittingly, boycotted by the Simon Commission. While all minorities ... have had their spokesmen, none has arisen to champion the fauna of India'. Appealing for the preservation of the tiger, he defended it from a charge of unlimited ferocity, describing it as usually 'a good-tempered placid creature, timid of mankind to an extent which must be experienced to be believed'. He spoke also of a pitched battle in the Sunderbans, between forest guards and poachers of monitor lizards, protected because of their predation on snakes, but already threatened by the demand for reptile-skin shoes.

Between the world wars, at a time when Africa was very much in the forefront of the Society's work, Waris pressed for national parks in India, showing more foresight than other members of the Committee which, 'after a long discussion', recorded their opinion that such parks were unnecessary because the Indian Forest Department was creating natural sanctuaries, and wild animals were increasing everywhere in forest areas. In 1949 we find Waris urging the need for a scientific enquiry into the claims of some animal products, especially rhinoceros horn, to have aphrodisiacal qualities, the cause of unlimited slaughter.

Thus, for nearly half a century, Waris worked actively for the Society in a difficult field, where all his efforts tended to be frustrated by increasing human population, yet where some progress has been made--for which a share of the credit must go to him.

Politically, Waris has been called a diehard of the British Raj, presumably because he believed that agreement between Muslim, Hindu, and other communities should precede abdication of British rule. Can anybody be sure that he was wrong?

LEOFRIC BOYLE

\section{Professor Jean-Georges Baer}

Professor Jean-Georges Baer, a Vice-President of FPS since 1962, who died in February at Neuchâtel, Switzerland, as reported in the last Oryx, was an eminent scientist, a former Director of the Institute of Zoology in the University of Neuchâtel, a parasitologist and author of many scientific publications. He was President of IUCN from 1958 to 1963, having joined the Executive Board in 1954, and continued to serve as a member of the Ecology Commission until his death. He acted as President of WWF during its formation, and was President Emeritus of the International Biological Programme. At one time President of the Scientific Committee of the Swiss 
National Park, he took a keen interest in the FPS's work in international wildlife conservation. He had planned to make a special visit to London in March for the dinner to mark Lord Willingdon's retirement as President, and it was with great sadness that we learned of his death the previous month.

\section{Britain and the Trade Convention}

\section{Solicitor General at Annual General Meeting}

Mr Peter Archer QC, MP, the Solicitor General, was the speaker at the FPS Annual General Meeting on July 2nd, presided over by our President. After being welcomed by Lord Zuckerman, Mr Archer, who is a member of FPS, gave us a forthright talk about conservation legislation. He pointed out that the day before the meeting, July 1st, had been a milestone for wildlife conservation with the coming into force of the International Convention on Trade in Endangered Species, twelve nations having ratified the Convention. Unfortunately, Britain was not one of them. He agreed that the UK was in a position to ratify, since UK legislation complied with the Convention, deriving from an Act passed in 1939 under war-time conditions, which 'works in a rusty, creaky sort of way'; but not all our dependent territories, whom we had promised to include in our ratification (and they could not be added later if we ratified without them) were prepared to accept this Act as a basis for their own legislation. New legislation is planned, but not yet drafted, and it was largely the bottleneck in the parliamentary draftsmen's office that is now blocking progress. There was a great shortage of skilled draftsmen.

Another delaying factor was the Government's belief that the Convention would be much more effectively worked if our trading partners, i.e. the other eight EEC member nations, ratified at the same time, and so far none had done so. 'The object of the Convention', said Mr Archer, 'is not to get a signature on a piece of paper, but to get effective control over the trade in endangered species. But we do intend, as soon as possible, to have a new Act which is tailor-made for the purpose'.

\section{Elections}

Lord Zuckerman spoke of the deaths of three Vice-Presidents of the Society during the year, all of whom had given long and much valued services: Syed W. Ameer Ali CIE ICS (retd.); Professor J.G. Baer, and Sir Julian Huxley FRS. One new Vice-President was elected, Lt Col C.L. Boyle OBE, former Hon. Secretary of the Society.

Three members of Council retired and were warmly thanked for their services: J.C. Cadbury, Dr Malcolm J. Coe and Ian S. MacPhail. Mr MacPhail's appointment as Public Relations Officer was confirmed. Five names put forward to fill the vacancies on Council were confirmed: G.T. Corley Smith CMG, Dr Keith Eltringham, Stuart Johnstone, the Hon. Ivor Montagu and Dr John Owen.

Sir Peter Scott, our Chairman proposed a vote of thanks to the Zoological Society of London for much help and kindness throughout the year and especially for the provision of office accommodation and services.

Council's proposal, put forward by the Hon. Treasurer, that the subscription should be raised from $£ 3$ to $£ 5$ was approved. (See page 224.) 